\title{
Autonomous catalytic hydrogen generator based on bioethanol steam reforming
}

\author{
L.Y. Dolgikh, A.I. Trypolskyi, I.L. Stolyarchuk, Y.I. Pyatnitsky, P.E. Strizhak \\ L.V. Pisarzhevskii Institute of Physical Chemistry of National Academy of Sciences of Ukraine, Prospekt Nauki, 31, \\ Kyiv, Ukraine, e-mail:atripolski@gmail.com
}

\begin{abstract}
The generator is based on bioethanol steam reforming over the developed ferrite catalyst. The generator admits the utilization of thermal energy of the reaction mixture for vaporization and heating the input water-alcohol mixture. The generator is characterized by a simple single-stage design without a stage for hydrogen purification.
\end{abstract}

Keywords - hydrogen, catalytic generator, bioethanol, steam reforming.

\section{Introduction}

The process of ethanol steam reforming (ESR) is a promising way for hydrogen production from liquid bio-materials: $\mathrm{C}_{2} \mathrm{H}_{5} \mathrm{OH}+3 \mathrm{H}_{2} \mathrm{O} \rightarrow 6 \mathrm{H}_{2}+2 \mathrm{CO}_{2}$. Theoretically, it allows obtaining $50 \%$ of hydrogen from ethanol and $50 \%$ of hydrogen from water. Hydrogen production from bioethanol by ESR does not affect the concentration of carbon dioxide in the atmosphere. Hydrogen produced via steam reforming from the renewable feed may be efficiently utilized for electric energy production, particularly, for small-scale electricity supply. Coupling the steam reforming with a fuel cell establishes a new kind of technology for power generation. Using portable power systems based on fuel cell application simultaneously resolves the two issues of hydrogen use, particularly, safe hydrogen storage and its transportation [1]. Using diluted bioethanol significantly reduces the energy cost compared to pure ethanol reforming. In the catalytic ESR process, the choice of the appropriate catalyst is a key factor for ethanol conversion and high hydrogen selectivity.

\section{The testing activity of ferrite catalysts for the ESR reaction}

Many solid catalysts have been explored for the ESR reaction, in the overwhelming majority, they were supported metals, including $\mathrm{Ni}, \mathrm{Co}, \mathrm{Cu}, \mathrm{Rh}, \mathrm{Ru}, \mathrm{Pd}$, Ir, and Pt [2]. An only a limited number of other types of catalysts have been employed for this reaction, among them, simple and complex oxides [3]. The comparative study of the ferrites $\mathrm{MFe}_{2} \mathrm{O}_{4}(\mathrm{M}=\mathrm{Mg}, \mathrm{Mn}, \mathrm{Fe}$, $\mathrm{Co}, \mathrm{Ni}, \mathrm{Cu}, \mathrm{Zn}$ ) as the catalysts for the ethanol steam reforming reaction has been performed. The nanoparticles of ferrites $\mathrm{MFe}_{2} \mathrm{O}_{4}$ were synthesized by two different procedures: by solvothermal decomposition of heteronuclear complexes $\left[\mathrm{MFe}_{2} \mathrm{O}\left(\mathrm{CH}_{3} \mathrm{COO}\right)_{6}\left(\mathrm{H}_{2} \mathrm{O}\right)_{3}\right] \cdot 2 \mathrm{H}_{2} \mathrm{O}(\mathrm{M}=$ $\mathrm{Mn}, \mathrm{Co}, \mathrm{Ni})$; by chemical co-precipitation method ( $\mathrm{M}=\mathrm{Mg}, \mathrm{Mn}, \mathrm{Fe}, \mathrm{Cu}, \mathrm{Zn})$. The catalytic properties of ferrites were investigated at $250-700{ }^{\circ} \mathrm{C}$.

The nanosize ferrites $\mathrm{MFe}_{2} \mathrm{O}_{4}(\mathrm{M}=\mathrm{Mg}, \mathrm{Mn}, \mathrm{Fe}, \mathrm{Co}, \mathrm{Ni}, \mathrm{Cu}, \mathrm{Zn})$ are catalytically active in the process of steam reforming of ethanol. The X-ray diffraction data of the ferrites before and after catalysis indicates that the crystal structure of $\mathrm{MnFe}_{2} \mathrm{O}_{4}$, as distinct from nickel, cobalt, and copper ferrites, remains completely unchanged; it was observed only agglomeration of the $\mathrm{MnFe}_{2} \mathrm{O}_{4}$ crystallites and appearance of a negligible amount of complex oxide $\mathrm{FeO} / \mathrm{MnO}$ as result of partial reduction of manganese ferrite. According to XRD and electron diffraction data of other investigated ferrites obtained by the co-precipitation method, the crystalline phases of ferrites $\mathrm{FeFe}_{2} \mathrm{O}_{4}, \mathrm{MnFe}_{2} \mathrm{O}_{4}, \mathrm{MgFe}_{2} \mathrm{O}_{4}$, and $\mathrm{ZnFe}_{2} \mathrm{O}_{4}$ with a lattice of the spinel type were identified. The stability of $\mathrm{MFe}_{2} \mathrm{O}_{4}$ ferrites depends on a reducing ability of $\mathrm{M}^{2+}$ cations in the conditions of the ESR where hydrogen is a reducing agent. 
Ethanol is converted on the studied ferrites into acetaldehyde and/or acetone, followed by acetaldehyde/acetone steam reforming to hydrogen and $\mathrm{CO}_{2}$; no $\mathrm{CO}$ was found out in the reaction products up to $500{ }^{\circ} \mathrm{C}$ for all explored ferrites. At higher temperatures, $\mathrm{CO}$ was found for $\mathrm{MnFe}_{2} \mathrm{O}_{4}$ only at $700{ }^{\circ} \mathrm{C}$, for $\mathrm{NiFe}_{2} \mathrm{O}_{4}$ and $\mathrm{CoFe}_{2} \mathrm{O}_{4}$ at $550-700{ }^{\circ} \mathrm{C}$ and $600-700{ }^{\circ} \mathrm{C}$, respectively. The maximum hydrogen yield decreases in order: $\mathrm{MnFe}_{2} \mathrm{O}_{4}>\mathrm{MgFe}_{2} \mathrm{O}_{4}>\mathrm{FeFe}_{2} \mathrm{O}_{4}$ $>\mathrm{CuFe}_{2} \mathrm{O}_{4}>\mathrm{CoFe}_{2} \mathrm{O}_{4}>\mathrm{ZnFe}_{2} \mathrm{O}_{4}>\mathrm{NiFe}_{2} \mathrm{O}_{4}$.

During ESR over $\mathrm{MnFe}_{2} \mathrm{O}_{4}-\mathrm{CP}$ catalyst prepared by co-precipitation method, almost $100 \%$ ethanol conversion is achieved in the temperature range between $500{ }^{\circ} \mathrm{C}$ and $600{ }^{\circ} \mathrm{C}$. Selectivity toward hydrogen reaches the maximum $\mathrm{S}_{\mathrm{H} 2}=84.3 \%$ at $550{ }^{\circ} \mathrm{C}$. The main reaction products are hydrogen and carbon dioxide. No detectable amount of carbon monoxide was found among the reaction products at $500-600{ }^{\circ} \mathrm{C}$. However, at $650{ }^{\circ} \mathrm{C}$ carbon monoxide formation was detected due to the reverse water-gas shift reaction. The ethanol conversion over the $\mathrm{MnFe}_{2} \mathrm{O}_{4}$-HP catalyst prepared by the solvothermal method is $90-100 \%$ in the temperature range of $500-650{ }^{\circ} \mathrm{C}$. This catalyst demonstrates higher selectivity toward hydrogen at $600-$ $650{ }^{\circ} \mathrm{C}$. The selectivity reaches $94.6 \%$. The formation of the carbon monoxide on the $\mathrm{MnFe}_{2} \mathrm{O}_{4}-$ HP catalyst is observed at $700{ }^{\circ} \mathrm{C}$. $\mathrm{MnFe}_{2} \mathrm{O}_{4}-\mathrm{CP}$ catalyst exhibits higher hydrogen yield in the temperature range between $450{ }^{\circ} \mathrm{C}$ and $550{ }^{\circ} \mathrm{C}$ compared to $\mathrm{MnFe}_{2} \mathrm{O}_{4}-\mathrm{HP}$ catalyst. In contrast, the higher hydrogen yield is observed on the $\mathrm{MnFe}_{2} \mathrm{O}_{4}-\mathrm{HP}$ catalyst for $\mathrm{T}>600{ }^{\circ} \mathrm{C}$.

\section{Technological design of the catalytic hydrogen generator}

The catalyst introduced in the present paper may be used for a portable autonomous hydrogen generator. That requires a simple technological scheme allowing one to easily operate. The autonomous catalytic hydrogen generator was developed under ISO 16110 Hydrogen generators using fuel processing technologies and IEC 62282-5-100 Portable fuel cell power systems requirements. The essential parts of a portable hydrogen generator are a fuel processing system, fuel cell module, fuel supply system, onboard energy storage system, and water treatment system. The fuel processing system provides fuel conversion into hydrogen. In the fuel cell module, hydrogen is converted into electric energy and heat in an electrochemical way. The obtained heat and electricity are further integrated into the energy generation system. Small power plants are typically based on proton-exchange membrane fuel cells (PEMFC) and solid oxide fuel cells (SOFC). We used the PEMFC. It works at low temperature $\left(<80^{\circ} \mathrm{C}\right)$ and does not sensitive to hydrogen purity, e.g., $\mathrm{CO}_{2}$ additives. For the calculations of the generator efficiency, we use the characteristics of the commercially available PEMFC produced by Horizon Fuel Cell Technologies Company.

According to the overall ESR reaction scheme, the stoichiometric molar ratio water/alcohol equals 3 , which corresponds to $46 \%$ of alcohol by weight. For a three-column scheme of the bioethanol synthesis, the grout distillate with an average alcohol content of approximately $40 \%$ (vol.) is obtained at the first column. This alcohol content is equivalent to the water/alcohol molar ratio of 3.5. We propose an approach to carry out ESR reaction in a single fixed bed reactor using the patented catalyst. A principal scheme of the hydrogen generator is shown in the figure. The applicability of a single-reactor scheme is governed by the developed $\mathrm{MnFe}_{2} \mathrm{O}_{4}-\mathrm{HP}$ catalyst that gives almost $100 \%$ of bioethanol conversion at $650^{\circ} \mathrm{C}$. Exceedingly small amounts of the reaction byproducts, e.g., oxygenates and $\mathrm{CO}$, are obtained. The amount of $\mathrm{CO}$ is only 50 - $60 \mathrm{ppm}$, which is suitable for PEMFC stable functioning. The unreacted bioethanol and reaction byproducts (oxygenates) do not affect the PEMFC operation. Carbon dioxide does not poise the Pt-Ru catalyst in the fuel cell, whereas water is required for stable fuel cell functioning. 


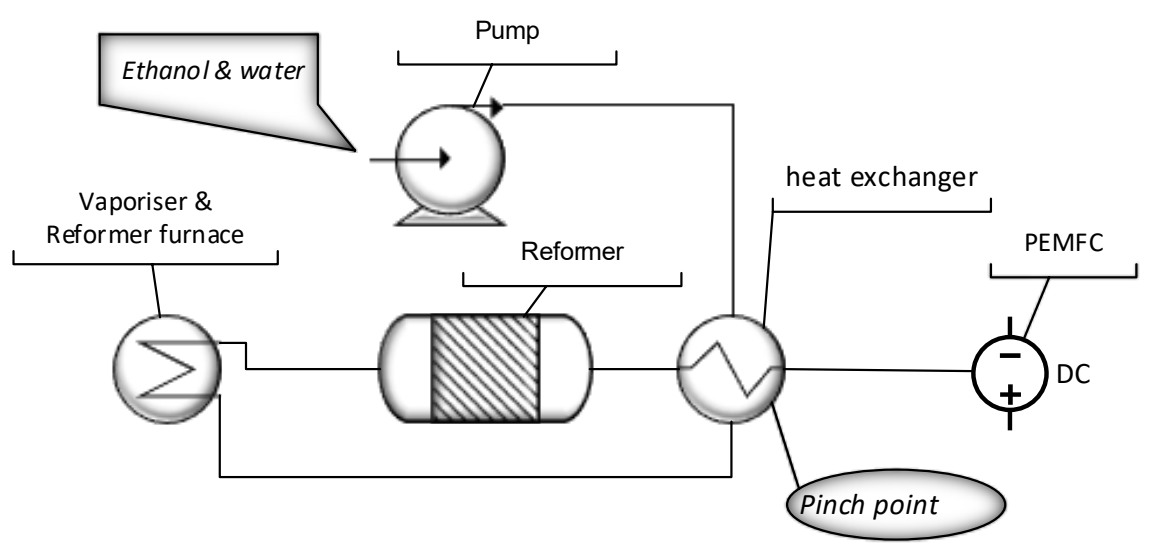

The presented scheme admits the utilization of thermal energy of the reaction mixture for vaporization and heating the input water-alcohol mixture. According to the scheme, the heat exchanger is placed between the reactor and fuel cell module and serves as a pinch zone. The pinch zone provides the flexibility of the water/alcohol ratio in the input mixture. The role of the water/alcohol ratio is crucial because this ratio significantly affects the alcohol conversion, hydrogen yield, as well as catalyst lifetime.

\section{Conclusion}

Hydrogen may be produced from renewable feedstock, e.g., bioethanol derived from biomass, using steam reforming. In this case, hydrogen yield significantly depends on the catalyst used and process conditions. Steam reforming is performed over the $\mathrm{MnFe}_{2} \mathrm{O}_{4}$ catalyst with spinel structure. Using this catalyst $98-100 \%$ ethanol conversion is achieved in the temperature range between 500 and $650^{\circ} \mathrm{C}$, whereas hydrogen yield reaches more than $90 \%$. Hydrogen obtained by steam reforming may be converted into electricity via the application of the fuel cells. Existing hydrogen power plants are inappropriate for small-scale electricity production. To this end, a single-stage autonomous catalytic hydrogen generator is developed. The developed generator does not contain hydrogen purification equipment and utilizes the heat of the reaction products. The energy conversion efficiency toward ethanol equals $44 \%$.

\section{Acknowledgments}

This research is partially supported by the Target Program of the National Academy of Sciences of Ukraine "Development of scientific grounds for hydrogen production, storage, and use in autonomous energy supply systems".

\section{References}

[1] Ni, M., Leung, D. Y. C., Leung, M. K. H. (2007). A review on reforming bio-ethanol for hydrogen production, Int. J. Hydrogen Energy, 32(15), 3238-3247. https://doi.org/10.1016/j.ijhydene.2007.04.038.

[2] Contreras, J. L., Salmones, J., Colín-Luna, J. A., Nuño, L., Quintana, B., Córdova, I., Zeifert, B., Tapia, C., Fuentes, G.A. (2014). Catalysts for $\mathrm{H}_{2}$ production using the ethanol steam reforming. Int. J. Hydrogen Energy 39(33), 18835-18853. https://doi.org/10.1016/i.ijhydene.2014.08.072.

[3] Dolgikh, L.Y., Pyatnitsky, Y.I., Strizhak, P.E. (2018). Hydrogen production from bioethanol on mixed oxide catalysts. In M. Brenzo, Bioethanol and Beyond: Advances in Production Process and Future Directions. Nova Science Publishers, Inc. https://novapublishers.com/shop/bioethanol-and-beyond-advances-in-production-processand-future-directions. 